\title{
Heat Shock Protein 70
}

National Cancer Institute

\section{Source}

National Cancer Institute. Heat Shock Protein 70. NCI Thesaurus. Code C17765.

A family of structurally related proteins that are involved in both protein folding and cellular stress responses. The members of this family are approximately $70 \mathrm{kDa}$. 